К - константа скорости сорбции кислорода;

С - концентрация кислорода;

$\mathrm{n}$ - порядок реакции по кислороду $(0<\mathrm{h}<1)$;

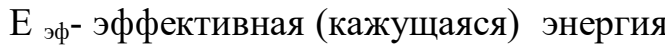
активации процесса окисления;

При этом величина $\delta=\frac{E}{\boldsymbol{R} T_{i}}$ $\frac{9}{2} r^{2} K C^{\prime \prime} e \frac{E}{R T}$, входящая в решение уравнения (10) определяет предельное условие стационарности процесса, т.е. $\mathrm{Q}_{1}=\mathrm{Q}_{2}$

$\mathrm{Q}_{1}$ - тепло, выделяющееся за счет реакции окисления материала;

$\mathrm{Q}_{2}$ - тепло, рассеивающееся путем теплопроводности и конвекции.

Такую модель можно реализовать на современных компьютерах, с целью выбора эффективного в технологическом и экономическом отношениях режима промыщленного хранения зерна.

Заключение

1. Установлен энергетический уровень активационного барьера $\mathrm{E}_{\mathrm{a}}=123$ кДж/моль зерновой массы, как термодинамической системы, при достижении которой в ней образуется устойчивый внутренний источник тепла. При этом, за счет анизатропии и пористости зерна и зерновой массы и под влиянием конвективных потоков в течение $3 . .6$ суток происходит спонтанное возникновение очагов самосогревания.

2. Аддитивность перечисленных процессов активизируют ферментные системы алейронового слоя, которые в присутствии кислорода усиливают экзотермические процессы, гидролизуют и расщепляют макромолекулы эндосперма зерна, включая клетчатку и, переводят зерновую массу из состояния покоя к активной жизнедеятельности и самосогреванию.

3. Для учета основных факторов и прогнозной оценки возможных экзотермических процессов и предотвращения самосогревания зерна (на токах, в элеваторах, при транспортировке, хранении и т.д.) предлагается использовать имитационную математическую модель.

\section{СПИСОК ЛИТЕРАТУРЫ}

1. Трисвятский Л.А. Хранение зерна. - М.: Колос, 1985. - 256 с.

2. Джанкуразов Б.О., Джанкуразов К.Б. Сохранить золотое зерно Казахстана. Алматы: Алейрон, 2014 г. - 165 с.

3. Егоров Г.А. Технология муки. Технология крупы. 4-ое издание, исправленное и дополненное. М.: Колос. 2005.-296 с.

4. Джанкуразов Б.О., Ахмеджанов Т.К., Джанкуразов К.Б. Стратификация в объеме зерновой массы и флуктуация тепло-влажностных параметров - как фактор спонтанного возникновения экзотермических процессов в зернохранилищах. Бишкек // «Вестник КНАУ», №1 (52). 2020. - c.106-116.

5. Ахмеджанов Т.К., Джанкуразов Б.О., Ильиных С.Н. Особенности самосогревания зерновых масс в силосах.// Вестник МОиН НАН РК, №2. - 2003. - C.74-79.

6. H. Özkaya, B. Özkaya, «ÖĞÜTME TEKNOLOJISI». - Ankara, 2005. - 757 c.

7. Джанкуразов Б.О., Изтаев А.И., Кулажанов К.С., Научные основы хранения зерна. -Алматы: Алейрон, 2002.-284 с

8. Джанкуразов К.Б. Разработка метода прогноза состояния и ресурсосбережения при обработке и хранении зерна: Автореф.дисс.канд.Алматы, 2010-21 с.

9. Кеннет Дж. Валентас Энрике Ротштейн Р. Пол Сингх «Пищевая инженерия». - Санкт Петербург: Профессия, 2004. - 848 с.

UDC 637.69

IRSTI 65.59.17

\title{
RESEARCH OF CAMEL SHANKS PROTEINHYDROLYZATES BY ELECTROPHOREGRAM
}

\author{
Zh.I. SATAYEVA ${ }^{l}$, A.M. TAYEVA ${ }^{1}$ \\ ('«Almaty Technological University» JSC, Almaty, Kazakhstan) \\ E-mail: julduz.kaynar@mai.ru; aigul_taeva@mail.ru
}

This research aims to study the degree of hydrolysis, determining the nature of protein hydrolyzates, which determine their size and molecular weight by the method of electrophoregram. In this research, a camel pancreas suspension was used to hydrolyze proteins from camel shanks. 
Sodium dodecyl sulfate-polyacrylamide gel electrophoresis (SDS-PAGE) was used to monitor the distribution of proteins and evaluate their molecular weights at different incubation times. Electrophoregram processing using the BioCapt program (Vilber Lourmat, France) determines the nature of the hydrolysis of protein and peptide profiles among hydrolyzates and the hydrolysis time for 8 hours shows the most significant accumulation of low molecular weight compounds with a molecular mass of $<20 \mathrm{kDa}$, which is a favorable result for the potential activity of peptides.

Keywords: camel shanks, pancreas, electrophoregram, protein hydrolyzates, low molecular weight peptides.

\title{
ЭЛЕКТРОФОРЕГРАММА ӘДІСІ АРҚЫЛЫ ТУЙЕ СИРАҒЫНЫН АҚУЫЗ ГИДРОЛИЗАТТАРЫН ЗЕРТТЕУ
}

\author{
Ж.И. СATAEBA ${ }^{1}$, A.M. TAEBA ${ }^{1}$
}

('«Алматы технологиялық университеті» АҚ, Алматы, Қазақстан)

E-mail: julduz.kaynar@mai.ru; aigul_taeva@mail.ru

Бұл зерттеудің мақсаты электрофореграмма әдісі арқылы ақуыз гидролизаттарының табигатын, олардың өлшемімен молекулалық массасын анықтайтын, гидролиз дәрежесін зерттеу болып табылады. Бұл зерттеуде түйе сиравынан ақуыздарды гидролиздеу үшін түйенің ұйқы безінің суспензиясы пайдаланылды. Ақуыздардың таралуын бақылау жсәне әртүрлі инкубация кезеңдерінде олардың молекулалық салмавын бавалау үшін полиакриламидті гельдегі натрий додецилсульфаты электрофорезі (SDS-PAGE) пайдаланылды. BioCapt (Vilber Lourmat, Франция) багдарламасын қолдана отырып электрофореграмманы өңдеу гидролизаттар арасындавы акуыз және пептидті профильдердің гидролизінің табигатын анықтайды жжәне 8 сагатқа созылатын гидролиз уақыты молекулалық массасы <20кДа төмен болатын молекулалық қосылыстардың ең көп жинақталуын көрсетеді, бұл пептидтердің ықтимал белсенділігі үшін қолайлы нәтиже болып табылады.

Негізгі сөздер: түйе сирақтары, ұйқы безі, электрофореграмма, ақуыз гидролизаттары, салмағы төмен молекулалық пептидтер.

\section{ИССЛЕДОВАНИЕ ГИДРОЛИЗАТОВ БЕЛКОВ ВЕРБЛЮЖЬИХ ГОЛЯШЕК МЕТОДОМ ЭЛЕКТРОФОРЕГРАММЫ}

\author{
Ж.И. СATAEBA ${ }^{l}$, A.M. TAEBA ${ }^{1}$
}

( ${ }^{1} \mathrm{OO}$ «Алматинский технологический университет», Алматы, Казахстан)

E-mail: julduz.kaynar@mai.ru,aigul_taeva@mail.ru

Целью данного исследования является изучене степени гидролиза, определяющего природу гидролизатов белков, обусловливающих их размер и молекулярную массу методом электрофореграммы. В этом исследовании использовалась суспензия поджелудочной железы верблюда для гидролиза белков из верблюжьих голяшек. Электрофорез в додецилсульфате натрия в полиакриламидном геле (SDS-PAGE) использовали для наблюдения за распределением белков и оценки их молекулярных масс в разное время инкубирования. Обработка электрофореграммы с помоцью программы BioCapt (Vilber Lourmat, Франция) определяет характер гидролиза белка и пептидных профилей среди гидролизатов и время гидролиза в течение 8 часов показывает наибольшее накопление низкомолекулярных соединений с молекулярной массой <20 кДа, что является благоприятным результатом для потенциальной активности пептидов.

Ключевые слова: голяшки верблюда, поджелудочная железа, электрофореграмма, гидролизаты белков, низкомолекулярные пептиды. 


\section{Introduction}

The growing well-being of the population, rapid growth, and urbanization require improved use of existing protein sources along with the development of new and sustainable food production. World protein demand is expected to double by 2050 . This is due to the growing recognition of the critical role of protein in healthy eating in general, and especially for children and a growing elderly population. Meat products are essential sources of protein in the human diet and contain essential amino acids, minerals, and vitamins [1].

Proteins, components necessary for all organisms, are integrated into cellular structures and perform certain functions, as in the case of hormones, antibodies, and enzymes [2]. Secondary products of fish, livestock and poultry processed are a source of protein and other vital nutrients with potential biological active properties, suitable for further processing and improving the value of other products. These include heads, bones, carcasses, blood, skin, viscera, hooves, and feathers. There are many possible solutions to extract valuable nutrients from these substances, and one of the most effective and promising is to obtain a protein hydrolyzate.

Recent scientific evidence suggests that dietary proteins not only serve as nutrients but can also modulate the physiological functions of the body [3]. Protein hydrolyzates of meat byproducts represent an exciting alternative to soy flour, since there are no nutritional factors or allergenic proteins, and large amounts of all essential amino acids are present [4].

Protein hydrolysates can be obtained by hydrolysis of meat products or secondary raw materials under the action of proteolytic enzymes or chemical agents. These hydrolyzates are composed of protein fragments: peptides of various sizes; poly-, three- and dipeptides and free amino acids, which are effectively absorbed in the intestine, and also significantly affect the taste of food [5]. Enzymatic hydrolysis is preferred among hydrolysis methods and has advantages associated with the internal characteristics of enzymes, such as selectivity for substrates, and processes carried out under milder thermal conditions $[6,7]$.

During enzymatic hydrolysis, the molecular weight of intrinsic proteins and peptides decreases, and the number of ionized groups increases, which leads to the appearance of new peptides that are less and more soluble in water. Enzymatic hydrolysis can be carried out either by using endogenous enzymes that are found naturally in the substrate or by adding commercially available exogenous enzymes [8].

The hydrolysis process involves several variables; specificity and activity of the enzyme, the ratio of the enzyme/substrate, $\mathrm{pH}$, temperature, time, and the interaction between the nutrients present in the feed during hydrolysis [6].

Obtaining protein hydrolyzates is a promising alternative to add value to meat products. Also, protein hydrolyzates can improve and change the functional, physicochemical, and sensory properties of meat products [9].

\section{Objects and methods of research}

Camel shanks, samples of liquid and dry hydrolyzate were the objects of research.

The following techniques were used in the research process:

- Determination of protein by the Bradford method;

-The fractional composition of protein hydrolyzates was determined on an electrophoregram BIO-RAD Consort EV265;

- Electrophoregrams of the studied samples were analyzed on a densitometer. Electrophoregram processing was done using the BioCapt program (VilberLourmat, France).

The collagen hydrolyzate of camel shanks was obtained by the enzymatic method. The homogenate of the pancreas of camel and cattle was used as an enzyme-containing raw material.

Before hydrolysis, purified, crushed onto disks weighing $50 \mathrm{~g}$ and mixed with distilled water in a ratio of 1:2 were decreased in a thermostated glass at a temperature of $95-98^{\circ} \mathrm{C}$ for 50-55 minutes in a water bath. After cooling, the released fat was separated $-2.3-2.8 \%$ of the mass of camel shanks.

To obtain a suspension, the camel's pancreas was crushed on a top with a hole diameter of 2-3 $\mathrm{mm}$, homogenized with distilled water at an enzyme: substrate (hydro module) ratio of 1:0.5, then ethanol in an amount of $2 \%$ was added to the resulting suspension as a preservative.

Protein isolates were hydrolyzed with a pancreatic suspension at an enzyme: substrate ratio (protein ratio) of 1:15. Thermostatic was carried out at a temperature of $45^{\circ} \mathrm{C}$ and a $\mathrm{pH}$ of 7.0 for $4,5,6,7,8,9$ hours until the proteins were completely dissolved. To inactivate the enzyme complexes and thermocoagulation the extra protein at the end of the hydrolysis, the obtained substrate enzyme complexes were 
cooked at a temperature of $90 \pm 2^{\circ} \mathrm{C}$ for 20 minutes with further cooling in ice water to $0^{\circ} \mathrm{C}$. The crude hydrolyzate consists of three phases: aqueous, solid, and fat. The solid phase contains bones and insoluble proteins. The fat phase is $0.2-0.5 \%$ by weight of the original fat. The aqueous phase is a water-soluble protein hydrolyzate, which is then further processed.

The biological activity of the hydrolyzate depends on the size of the particles and their solubility. The biological and nutritional properties of protein hydrolyzates are determined by the average molecular weight $[9,10,11]$.

Determination of protein by the method of Bradford.12 $\mu \mathrm{l}$ was taken from the fresh hydrolyzate, dried in a thermostat, or using freeze-drying, then $80 \mu \mathrm{l}$ of urea was added to the precipitate, buffer for diluting samples with 2-mercaptoethanol $30 \mu \mathrm{l}$, after stirring, was kept in a thermostat at 95 degrees $45 \mathrm{~min}$. Further, 10 $\mu \mathrm{l}$ of a fresh sample was used for electrophoresis. Then electrophoresis was performed on PAGE $12 \%$, and staining was performed according to the Bradford method.

Analysis of proteins by electrophoresis in SDS-PAGE (polyacrylamide gel with sodium dodecyl sulfate). The initial hydrolyzed, soluble and insoluble fractions were analyzed by electrophoregram in $12 \%$ SDS-PAGE according to the method of U.K. Laemmlietal using an apparatus for vertical electrophoresis (Bio-Rad, USA). Wellcleaned washed and fat-free glass plates $(7 \times 10)$ were installed using gaskets and clamps. The space between the plates was poured with a solution for a separating gel consisting of $3.5 \mathrm{ml}$ of $30 \%$ acrylamide; $3.1 \mathrm{ml}$ of $1 \%$ bisacry-lamide; $7.5 \mathrm{ml}$ of $1.5 \mathrm{M}$ Tris- $\mathrm{HCl}(\mathrm{pH} 8.7) ; 6.5 \mathrm{ml}$ of distilled water; $0.03 \mathrm{ml} \mathrm{10 \%} \mathrm{SDS;} 0.001 \mathrm{ml}$ TEMED and $0.01 \mathrm{ml}$ $10 \%$ ammonium persulfate. After polymerization of the lower gel, the remaining space is poured into the solution to concentrate the gel. The solution is prepared as follows: $1 \mathrm{ml}$ of $1 \%$ bisacrylamide; $1 \mathrm{ml}$ of $30 \%$ acrylamide is mixed; $5.35 \mathrm{ml}$ of distilled water; $2.5 \mathrm{ml} 0.5 \mathrm{M}$ Tris- $\mathrm{HCl}(\mathrm{pH} 6.8) ; 0.01 \mathrm{ml} \mathrm{10 \%}$ SDS; $0.05 \mathrm{ml} 10 \%$ ammonium persulfate and 0.005 $\mathrm{ml}$ TEMED. Immediately after pouring the concen- trating gel, a comb was set until complete polymerization.

A sample dilution buffer was prepared as follows: $0.25 \mathrm{ml}$ of 2-mercaptoethanol was added to $0.315 \mathrm{ml}$ of $1 \mathrm{M}$ Tris- $\mathrm{HCl}$ (pH 6.8); 0.5 $\mathrm{ml}$ glycerol, $0.115 \mathrm{ml} \mathrm{10 \%} \mathrm{SDS;} 0.05 \mathrm{ml}$ of $0.1 \%$ bromophenol blue and distilled water were added to a volume of $5 \mathrm{ml}$. Then, the obtained samples were diluted in a ratio of 1:1, boiled in a water bath for 3-5 minutes and then cooled.

Electrophoresis was performed at a current of $20 \mathrm{~mA}$ per chamber. At the end of the process, the gel was removed from the plates, staining was carried out for 1 hour in a CoumassyR-250 solution, then washed several times with a bleaching solution until the initial background color disappeared.

The liquid protein hydrolyzate was centrifuged at $10,000 \mathrm{G}$ on an Eppendorf Centrifuge $5810 \mathrm{R}$ for 20 minutes. After separation of the solid phase, the supernatant was dried on a NanBei spray dryer. The temperature at the inlet to the dryer ranged from 138 to $141^{\circ} \mathrm{C}$ and the temperature at the outlet ranged from 58 to $60^{\circ} \mathrm{C}$. The yield of dry hydrolyzate was $6.5-$ $6.8 \%$ by weight of camel shanks. The resulting hydrolyzate is a homogeneous finely divided powder of light beige color, with a weak specific odor, readily soluble in water.

\section{Results and their discussion}

The degree of hydrolysis determines the nature of hydrolyzates, determining their size and molecular weight. The fractional composition of protein hydrolyzates obtained with the use of the enzyme complex SPL of camel, depending on the duration of hydrolysis, was determined on an electrophoregram BIO-RAD Consort EV265. Electrophoregrams of the studied samples were analyzed on a densitometer. Electrophoregram processing was done using the BioCapt program (Vilber Lourmat, France).

Figure 1 shows the electrophoresis profiles of sodium dodecyl sulfate in polyacrylamide gel (SDS-PAGE) for protein hydrolyzates taken at different incubation times. 


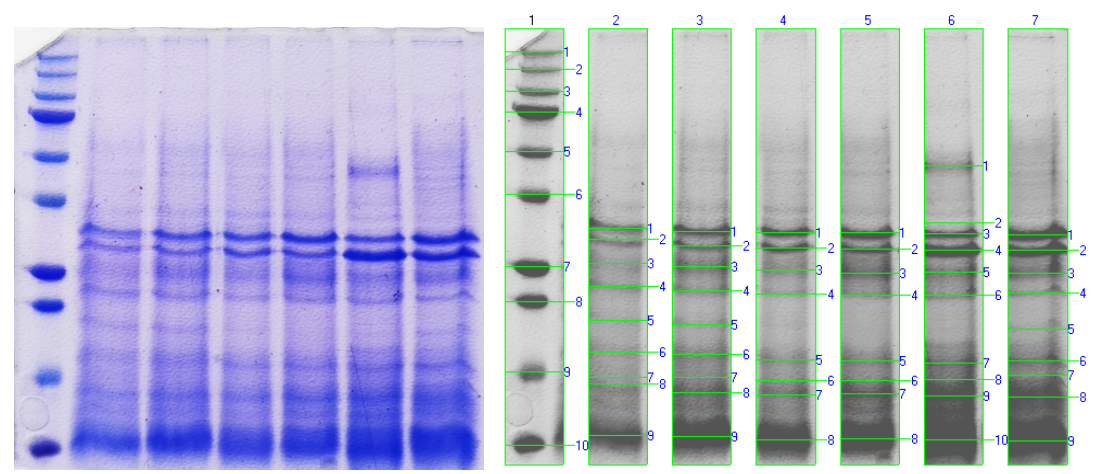

Figure 1 - Electrophoregram separation of the hydrolyzate on a $12 \%$ polyacrylamide gel Note:

Lane 1 - Molecular Marker - kDa, (Kaleidoscope ${ }^{\mathrm{TM}}$ Prestained Protein Standards, Bio-Rad)

Lane 2 -Sample 1, 4 hourshydrolysis, Lane 3-Sample 2, 5 hourshydrolysis

Lane 4-Sample 3, 6 hourshydrolysis, Lane 5-Sample 4, 7 hourshydrolysis

Lane 6-Sample 5, 8 hourshydrolysis, Lane 7 - Sample 6, 9 hourshydrolysis

The results indicate that protein hydrolysis continues with an increase in incubation time. But the hydrolysis time for 8 hours shows the most significant accumulation of low molecular weight peptides. Precise profiles of protein hydrolysates show that they have mixed peptides in small amounts. Low molecular weight peptides (2-20 amino acids) are more biologically active than their parent polypeptides/proteins, which are more significant [14]. The process of enzymatic hydrolysis is mainly determined by whether the type of protease involved is endopeptidase or exopeptidase [15]. Endopeptidase and exopeptidase are two types of peptidase enzymes. They cleave peptide bonds in protein molecules. A pancreatic suspension releases these peptidases to maximize protein breakdown. Endopeptidase cleaves peptide bonds within protein molecules and leads to the formation of peptide chains, rather than monomers. Exopeptidase cleaves peptide bonds at the ends and leads to individual amino acids [16]. Thus, the activity of endopeptidase and exopeptidase contributed to the further phased hydrolysis of proteins.

The results of the quantitative determination of protein fractions performed using the BioCapt program (Vilber Lourmat, France) are shown in table 1.

Table 1 - Molecular weight of protein fractions of hydrolyzates, kDa

\begin{tabular}{|r|r|r|r|r|r|r|r|}
\hline M.W. Values & Lane 1 & Lane 2 & Lane 3 & Lane 4 & \multicolumn{1}{c|}{ Lane 5 } & \multicolumn{1}{c|}{ Lane 6 } & \multicolumn{1}{c|}{ Lane 7 } \\
\hline Band 1 & 250.000 & 31.259 & 30.710 & 30.527 & 30.527 & 45.324 & 30.163 \\
\hline Band 2 & 150.000 & 29.436 & 28.354 & 27.995 & 27.817 & 32.177 & 27.638 \\
\hline Band 3 & 100.000 & 25.521 & 25.000 & 24.490 & 23.981 & 30.345 & 23.981 \\
\hline Band 4 & 75.000 & 22.015 & 21.400 & 20.957 & 20.814 & 27.638 & 21.103 \\
\hline Band 5 & 50.000 & 18.159 & 17.810 & 15.660 & 15.601 & 24.150 & 17.486 \\
\hline Band 6 & 37.000 & 16.075 & 15.955 & 14.486 & 14.486 & 20.814 & 15.601 \\
\hline Band 7 & 25.000 & 14.683 & 14.683 & 13.585 & 13.657 & 15.483 & 14.811 \\
\hline Band 8 & 20.000 & 14.285 & 13.729 & 10.404 & 10.485 & 14.552 & 13.441 \\
\hline Band 9 & 15.000 & 10.727 & 10.647 & & & 13.513 & 10.324 \\
\hline Band 10 & 10.000 & & & & & 10.404 & \\
\hline
\end{tabular}

From a comparison of densitograms, we can conclude that the most assimilable low molecular weight peptide fractions with molecular weights of 8-25 kDa of 53.4 and $39.6 \%$ (samples 6 and 7) were obtained by enzymatic hydrolysis of the camel pancreatic suspension by the enzyme complex for 8-9 hours respectively.

Qualitative indicators of the obtained dry enzymatic hydrolyzate of proteins from camel shanks are presented in table 2 . 
Table 2 - Physic-chemical parameters of dry protein hydrolyzate from camel shanks

\begin{tabular}{|l|l|}
\hline \multicolumn{1}{|c|}{ Name of indicator } & \multicolumn{1}{c|}{ Characteristic } \\
\hline Appearance & $\begin{array}{l}\text { Dry product of homogeneous consistency in the form of } \\
\text { loose powder, hygroscopic }\end{array}$ \\
\hline Color & Light beige \\
\hline Smell & Intrinsic to the raw material of which it is made, odorless \\
\hline Moisture content, $\%$ & 7,0 \\
\hline Mass fraction of protein, $\%$ & 80,0 \\
\hline Mass fraction of fat, $\%$ & 0,15 \\
\hline Mass fraction of ash, $\%$ & 5,0 \\
\hline
\end{tabular}

Thus, the resulting protein hydrolyzate containing low molecular weight protein fractions and amino acids with nutritious properties will be used in further work to enrich meat products for the elderly.

\section{Conclusion}

Research results of the nature of protein hydrolysis and peptide profiles among hydrolyzates confirmed that the enzymatic hydrolysis of camel shanks by a camel pancreas suspension was useful for producing low molecular weight compounds with a molecular weight of $<20 \mathrm{kDa}$, which is a favorable result for the potential biological activity of peptides.

In general, the hydrolysis process improves the digestibility of the protein, increases the bioavailability of amino acids, and leads to improved nutritional value. Protein hydrolyzates will be used as alternative ingredients of high nutritional quality with potential use for the production of meat products for herodietic purposes.

\section{REFERENCES}

1. Boland M.J., Rae A.N., Vereijken J.M., Muwissen P.M., Fisher Ar.R.H., van Boekel M.A.J.S. et al. (2013) The future supply of animal-derived protein for human consumption. Trends Food Sci \& Technology 29(1), 2013. - PP. 62-73.

2. da Silva, R.R. Bacterial and Fungal Proteolytic Enzymes: Production, Catalysis, and Potential Applications. Applied Biochemistry Biotechnology. 2017 Sep;183(1):1-19.

3. Chakrabarti S, Guha S, Majumder K. FoodDerived Bioactive Peptides in Human Health: Challenges and Opportunities. Nutrients. 2018; 10(11):1738. Published 2018 Nov 12.

4. Martínez-Alvarez, O., Chamorro, S., Brenes, A. (2015) Protein hydrolysates from animal processing by-products as a source of bioactive molecules with interest in animal feeding: A review. Food Research International, 73. - PP. 204-212.

5. Kristinsson H.G., Rasco B.A. Biochemical and Functional Properties of Atlantic Salmon (Salmo
Salar) Muscle Proteins Hydrolyzed with Various Alkaline Proteases. J Agricultural Food Chemistry.2000;48(3). - PP. 657-666.

6. Dieterich F., Boscolo W.R., Pacheco Bertoldo M.T., et al. Development and characterization of protein hydrolysates originated from animal agro-industrial byproducts. J Dairy Veterinary \& Animal Research 2014;1(2):56-61.

7. Bhat, Zuhaib \& Kumar, Sunil \& Bhat, Nina. (2015). Bioactive peptides from the egg: A review. Nutrition \& Food Science. 45, 190-212. DOI: 10.1108/NFS-10-2014-0088.

8. Aspevik, T., Oterhals, Å.,Rønning, S.B. et al. Erratum to: Valorization of Proteins from $\mathrm{Co}$ - and By-Products from the Fish and Meat Industry. Top $\begin{array}{llll}\text { Curr } & \text { Chem } & \text { (Z) 375, } 57 & \text { (2017). }\end{array}$ https://doi.org/10.1007/s41061-017-0146-3.

9. Gómez-Guillén, M.C.; Giménez, B., LópezCaballero M.E., Montero M.P. Functional and bioactive properties of collagen and gelatin from alternative sources: A review. Food Hydrocolloids.2011 Dec;25(8). - PP. 1813-1827.

10. Choi, D.; Min S.-G.; Jo Y.-J. Functionality of porcine skin hydrolysates produced by hydrothermal processing for the liposomal delivery system. Journal of Food Biochemistry. 2018.- 42(1). - e12464. Doi.org/10.1111/jfbc. 12464

11. Khiari Z.; Ndagijimana M.; Betti M. Low molecular weight bioactive peptides derived from the enzymatic hydrolysis of collagen after isoelectric solubilization/precipitation process of turkey byproducts. Poultry Science.- 2014. - 93(9). - PP. 2347-2362. doi.org/10.3382/ps.2014-03953.

12. Berdutina A.V. Development of the technology of protein hydrolysates from secondary raw materials of the meat industry [In Russian]. PhD. D. thesis. - M., 2000. - 186 p.

13. Surnin E.V. Development of technology for herodietic sausages enriched with biologically active ingredients from pork legs [In Russian] // PhD. D. thesis. - M., 2001. - 137 p.

14. Chen N., Yang H., Sun Y., Niu J., Liu S. Purification and identification of antioxidant peptides from walnut (Juglans regia L.) protein hydrolysates. Peptides. - 2012 Dec;38(2). - PP. 344-349.

15. Li B., Chen F., Wang X., Ji B., Wu Y. Isolation and identification of antioxidative peptides 
from porcine collagen hydrolysate by consecutive chromatography and electrospray ionization-mass spectrometry //Food Chemistry. 2007; 102(4). - PP. $1135-1143$
16. "Endopeptidase." Egyptian Journal of Medical Human Genetics, Elsevier. Britannica, edition of the encyclopedia. "Proteolytic enzyme." Encyclopedia Britannica, Encyclopedia Britannica, Inc. May 31. - 2018.

ӘОЖ 636.6

МРНТИ 65.59.91

\title{
ҚҰС ШАРУ АШЫЛЫҒЫНДА ПРОБИОТИКАЛЫҚ ПРЕПАРАТТАРДЫ қОЛДАНУДЫН ТИІМДІЛІГІ
}

\author{
Н.Ж. БЕГДІЛДАЕВА ${ }^{1}$, Ш.Н. АХМЕТСАДЫҚОВА ${ }^{2}$, \\ A.К. ҚҰДАЙБЕРГЕНОВА, Н.Н. АХМЕТСАДЫҚОВ
}

\author{
(«Алматы технологиялық университеті» АК, Алматы, Қазақстан ${ }^{1}$ \\ «Антиген» Ғылыми - өндірістік кәсіпорны ЖШС, Алматы, Қазақстан ${ }^{2}$ \\ Әл- Фараби атындағы Қазақ Ұлттық Университеті³) \\ E-mail: nzhumankyzy@mail.ru
}

Қазақстанда сапалы құс еті мен жұмыртқава сұраныстың өсуіне байланысты экологиялық таза өндіріске көшу өзекті болып табылады. Құс фабрикаларында пробиотиктерді қолдану өнімнің қауіпсіздігі мен экономикалық тиімділікті қамтамасыз етуге мүмкіндік береді. Бұл мақалада әлемде және отандық құс иаруашылызында пайдаланылатын пробиотикалық препараттарды қолданудың тиімділігі туралы деректер келтірілген. Пробиотиктерді енгізу арқылы ет, жұмыртқа және құс қаңқасының сапасы жақсаратыны, антибиотиктерге төзімділік концентрациясы 1,5-2\%-zа және иммунитеті жсогарылайтыны, азықтың конверсиясы 5-7\%-zа жақсаратыны, бақылау топтарымен салыстырzанда тауықтардың дене салмагы 1,1\%-дан 3,9\%-zа дейін артатыны дәлелденді. Зерттеу жсұмысының тәжірибелік маңызы қазақстандық құс фабрикаларында қолданылатын шетелдік пробиотиктер нарывын және олардың тиімділігін зерттеу болып табылады.

Негізгі сөздер: пробиотикалық препараттар, құс шаруашылығы, құс өнімділігі, азықтық коспалар, кұс еті.

\section{ЭФФЕКТИВНОСТЬ ПРИМЕНЕНИЯ ПРОБИОТИЧЕСКИХ ПРЕПАРАТОВ В ПТИЦЕВОДСТВЕ}

\author{
Н.Ж. БЕГДИЛДАЕВА', Ш.Н. АХМЕТСАДЫКОВА \\ A.К. КУДАЙБЕРГЕНОВА ${ }^{3}$, Н.Н. АХМЕТСАДЫКОВ
}

(Алматинский технологический университет, Алматы, Казахстан ${ }^{1}$ ТОО Научно-производственное предприятие «Антиген», Алматы, Казахстан ${ }^{2}$ Казахский Национальный университет им. Аль - Фараби, Алматы, Казахстан $\left.{ }^{3}\right)$ E-mail: nzhumankyzy@mail.ru

В связи с растущим спросом на качественное мясо птицы и яйца в Казахстане переход на экологически чистое производство является как никогда актуальным. Применение пробиотиков на птицефабриках может обеспечить безопасность продукции и экономическую эффективность. В данной статье представлены данные об эффективности применения пробиотических препаратов, используемых в мире и в отечественном птицеводстве. Доказано, что за счет внедрения пробиотиков улучиается качество мяса, яиц, и каркаса птиц, повышается иммунитет и устойчивость к антибиотикам 1,5-2\%-ной концентрации, улучшается конверсии корма на 5-7\%, увеличивается вес живой массы тела от 1,1\% до 3,9\% по 